\title{
The Vilamovicean Passive
}

Keywords: Germanic linguistics, endangered and minority languages, verbal system, passive.

\section{Introduction}

Vilamovicean (Wymysöeryś [vimisø:rıc]) is a Germanic language spoken in the town of Wilamowice situated in Western Galicia on the boundary with Silesia. According to the contemporary administrative division, Wilamowice constitutes a part of the Silesian Province (Województwo Śląskie), in the southern part of Poland. Like other Silesian vernaculars, it is a Central East German dialect which derives from Middle High German. Nowadays, Vilamovicean is the smallest Germanic language in the world: it is understood by roughly eighty persons, but actively employed by no more than twenty fully competent speakers. The fact that the language is used by a highly limited number of native speakers (among whom all are older than 80 years) and that, furthermore, there is no committed policy in the protection or popularization of Vilamovicean among younger members of the community, necessarily implies that its future is in real danger. According to the most probable scenario, in approximately ten years the actively spoken language will have disappeared entirely. Therefore, it is extremely important to collect as much grammatical evidence as possible concerning Vilamovicean: in that manner, we hope to be able to compile a complete picture of the language (built on 
the empirical data and contrasted with native speakers' competition) before it dies for ever.

The present paper, which forms a part of a wider project conducted by the author in collaboration with Tymoteusz Król - and which aims at writing a compendious Vilamovicean grammar as well as an extensive Vilamovicean-Polish-English dictionary - will deal with one aspect of the Vilamovicean verbal system, namely the passive voice, and in particular with its uses and meanings. ${ }^{1}$ This matter has almost entirely been omitted in all - extremely scarce - existing grammatical descriptions of the language. Młynek (1907), Kleczkowski (1920) and Wicherkiewicz (2004) completely ignore the question of the passive, and Lasatowicz (1992: 74-75) limits herself to a superficial observation that the dialect includes only one passive construction employed in three tenses: passive perfect dos ej gymoht wada ${ }^{2}$, passive pluperfect dos vör gymoht wada and passive future perfect dos werde gymoht wada. In all three cases, the formation perfectly matches the corresponding German constructions, respectively ist geschlagen worden, war geschlagen worden and wird geschlagen werden. As will be demonstrated in the next section, the paradigm provided by Lasatowicz (1992) is far from being accurate and exhaustive. Besides the sweeping character of her affirmation, the principal objection against Lasatowicz's grammatical overview consists in the fact that she does not specify the source of the data (number of speakers, their names and age, etc.). In fact, the entire grammatical model provided by Lasatowicz has a suspiciously German character and various forms (e.g. the conjugation of the past forms of the verb zajn 'be') given as norms are unrecorded in the database developed by Tymoteusz Król and Alexander Andrason since 2007. Consequently, Lasatowicz's book cannot be regarded as trustworthy information on the language - though it can show some interesting variations extrapolated from a vernacular employed by one or more speakers, a variant which in some aspects importantly diverges from the linguistic system used by all informants in our studies.

As will be demonstrated in the following sections of the article, the passive voice can be expressed in Vilamovicean not through one but through

1 This means that a detailed syntactic behavior and structural properties of the passive constructions will not be studied.

${ }^{2}$ Lasatowicz's examples - originally provided in the IPA phonetic transcription - are spelled here using the convention developed by Tymoteusz Król and Alexander Andrason. 
three periphrastic locutions which employ an auxiliary verb and a passive participle. Furthermore, in each of these formations the auxiliary may appear in various tenses (Future, Present, Preterite, Perfect and Pluperfect). In section 1, the expression built on the verb zajn 'be' will be presented. Afterwards in section 2, we will discuss the passive construction that uses the auxiliary wada 'become', while in section 3, the formation which includes the verb błajn 'remain' will be analyzed. Finally in section 4, we will summarize and contrast all the previously introduced means of conveying the passive value, proposing a final general conclusion.

For the study of passive expressions nineteen persons with the best proficiency in Vilamovicean were chosen: Kazimierz Grygierczyk (1913), Anna Danek (1916), Anna Schneider (1920), Elżbieta Młynarska 'Milerka' (1921), Helena Biba 'Płacznik' (1922), Anna Zejma 'Luft' (1923), Elzbieta Babiuch (1923), Elżbieta Matysiak, 'Hala-Mockii’ (1924), Helena Gasidło (1924), Waleria Brzezina 'Cepok' (1925), Rozalia Hanusz 'Linkuś' (1926), Stanisław Fox 'Luft' (1926), Anna Fox 'Luft' (1927), Helena Rozner 'Biba' (1928), Helena Nowak (1928), Inga Danek (1928), Józef Gara (1929), Elżbieta Gandor (1930) and Emilia Danek (1933). Our field research (carried out in August 2009 and October 2010) included two tasks: on the one hand the native speakers were asked to translate Polish passive sentences and on the other hand, they were required to evaluate the correctness and specify the exact meaning of Vilamovicean examples. ${ }^{3}$

It should be emphasized that since - aside from several poems composed by Florian Biesik at the beginning of the 20th century (and some other scarce texts $\left.^{4}\right)$ - there is no Vilamovicean literature, the field work conducted by the author seems to be the only reliable source of the contemporary state of the language.

One shall also note that the author follows the Vilamovicean spelling convention which has been proposed by Tymoteusz Król and which he has himself already employed both in the work on the Vilamovicean Grammar and

3 Theses examples were either those proposed by the speakers themselves (i.e. they had to explain what they exactly meant providing a determined translation of the Polish sentence) or corresponded to phrases composed by the author of the present article.

${ }^{4}$ For a review of all written records of the Vilamovicean language see Wicherkiewicz (2004). Additionally, it should be noted that some songs were recently published by Dobczyński (2002), Gara (2006) and Danek (2007). 
in all published articles and given talks (cf. Andrason 2008a, 2008b, 2009, 2010a and 2010b).

\section{Zajn passive}

The passive in zajn corresponds to a periphrasis composed by the auxiliary zajn 'be' and the passive participle, e.g. gymoht 'done'. Depending on the tense of the auxiliary verb (Future, Present, Preterite, Perfect or Pluperfect) the construction can provide various meanings. In the present section, we will describe all such variations of the zajn passive and their possible values. ${ }^{5}$

\section{1. wyt zajn gymoht}

When the verb zajn stands in the Future tense ${ }^{6}-$ in the $3^{\text {rd }}$ person singular taking the shape wyt zajn, and in the $3^{\text {rd }}$ plural wan zajn $n^{7}$ the periphrasis can function as a dynamic progressive future indicating that a given event will be in progress of being performed:

5 When we state that a given construction is used with a certain temporal, aspectual or taxis (perfect) force, we intend to say that it is compatible with that value. In each case, the meaning is clearly imposed by the context which makes such temporal (e.g., con jür $y$ dom 'ten years ago'), aspectual (e.g., a gonca tog 'the whole day') or taxis (e.g., eta 'already' or eta grod 'already, right now') connotations explicit. Thus, when describing the semantic-functional potential of each variant of the three periphrases, we will demonstrate its compatibility with a given unambiguous tense-aspect-taxis environment. The computation of all acceptable contexts will constitute the "inherent" meaning of the construction (this understanding of the meaning of verbal formations harmonizes with ideas formulated by Dahl 2000 and Bybee, Perkins \& Pagliuca 1994).

6 The explicit future activities are most frequently conveyed by the so called "wada Future" which consists of the auxiliary wada and the infinitive of the main verb, e.g. wyt moha 'will do' (Andrason 2010b). Thus, the future passive described in this section will surface in the wada Future as wyt zajn gymoht 'will be done'. Other possible future constructions may use the introductory verb zuła 'shall' (giving the passive form zo zajn gymoht) or various modal auxiliaries such as müssa 'must' or mygja 'may' (for a review of all possible future expressions in the Vilamovicean language see Andrason 2010b).

7 It should be noted that these forms, i.e. $w y t$ and wan, differ from the "regular" $3^{\text {rd }}$ persons of the verb wada when used as a main verb with the meaning 'become' and not as a future auxiliary ( $3^{\text {rd }}$ singular wjyd and $3^{\text {rd }}$ plural wada). 
(1) a. Mün wyt dos hoüz zajn gymöltt ${ }^{8}$ a gonca tog

Tomorrow will the house be painted a whole day

Tomorrow the house will be being painted the whole day (i.e. someone will be painting it) ${ }^{9}$

b. Mün ym mytag wyt dy kjyh zajn reperiyt

Tomorrow at-the noon the kitchen will be repaired

Tomorrow at noon, the kitchen will be being repaired (i.e. someone will be repairing it)

The same construction may also function as a simple future with no progressive nuances available. In that case, it denotes simple general events, including habitual and permanent ones (2a and 2.b).

(2) a. Wymysiöejer śpröh wyt nymer ny zajn fergasa

Vilamovicean language will never not be forgotten

The Vilamovicean language will never be forgotten (i.e. they will not forget it)

b. Dy wymysiöejer kyndyn wan ind gyljyt zajn cy kuza wymysiöeryś

The Vilamovicean children will always taught be to speak Vilamovicean

Vilamovicean children will always be taught to speak Vilamovicean (i.e. people will always teach them)

Furthermore, the formation frequently expresses future perfect events indicating that a given prospective event will occur before another future action (3.a and 3.b). The periphrasis may be employed to indicate future stative (resultative non-dynamic) situations (3.c). In these instances the construction conveys nuances suggesting a resultative endpoint and/or a static conclusion

8 The relevant Vilamovicean forms that convey the passive meaning will be given in bold type.

9 Through-out the article, we will also provide active meanings which are equivalent to the exact and literal passive translations. These meanings will be put in parentheses. In that manner, the intended taxis, aspectual or temporal values will be clarified and made more explicit. It shall be noted that the meanings put in parentheses were meanings which the informers "had in mind" when translating underlying Polish sentences or when judging the acceptability and specifying the sense of a given example. 
of a future activity contrasting with a clearly non-resultative and dynamic sense of examples 1.a and 1.b, presented above.

(3) a. Fir draj jür, wen haor kum cyryk, wyt dy śtrös zajn gyboüt In three years, when he comes back, will the street be built In three years, when he returns, the street will be constructed (i.e. they will have built it)

b. Wen yh kum cyryk, wyt dy wond śun zajn gymölt When I come back, will the wall already be painted

When I come back, the wall will already be painted (i.e. they will have painted it)

c. Ym mytag wyt śun dos mytagasa zajn gykoht

At noon will already the lunch be cooked

At noon, the lunch will already be cooked (cf. the Polish original perfective future będzie ugotowany, i.e. the subject will encounter a stative situation of a lunch being ready)

\section{2. ej gymoht}

When the zajn passive employs the auxiliary verb in the present tense giving, in the $3^{\text {rd }}$ person singular, the shape ej gymoht - the periphrasis can provide various meanings. Frequently, it approximates a resultative stative (a present static situation viewed as resulting from a previously performed action, such as in English is done) and a present perfect (a dynamic anterior event currently relevant for the present state of affairs, such as in English has been done) (4):

\section{Dos hoüz ej śun gyboüt}

The house is already built

The house is already built / has been built (i.e. someone has been built the house and it stands ready)

Consequently, the above quoted sentence can have two possible readings: one static - the house appears as ready to move in; and the other dynamic the construction of the house has concluded. As already mentioned, the former equals a present (resultative) stative while the other approximates a passive (resultative) present perfect.

Moreover, the ej gymoht passive pattern can be used with the value of a present progressive passive indicating that a given activity is being per- 
formed at the very moment of the enunciation (5.a and 5.b). Here, in contrast to example (4) above, the periphrasis does not provide any evident resultative or anterior nuances. Furthermore, opposite to the stative reading of the passive in (4), the value of the passive voice in sentences quoted below is invariably dynamic.

(5) a. Wos höt zih dö? Dos hoüz ej eta gymölt

What has itself there? The house is now painted

What is happening over there? The house is now being painted (i.e. someone is painting it)

b. Wu ej s'oüta? S'ej eta grod gyryht

When is the-car? It already right-now repaired

Where is the car? It is being repaired (i.e. someone is repairing it)

The construction may also be employed with the simple present passive force describing regular, habitual or universal events and activities:

(6) a. Dy oüta zajn gyrjyt diöh dy benzyn

The cars are driven by the gas

Cars are propelled by gas (i.e. gas propels / serves to propel cars)

b. Dy kyndyn zajn azu ufgycün, do zy zuła śunn zajna ełdyn

The children are so educated that they should respect their parents

Children are educated so that they would respect their parents (i.e. people always educate their children in that manner)

Furthermore, the expression can denote events that began in the past and continue being performed in the present time frame approximating the meaning of an inclusive (universal) present perfect:

Dos hoüz ej śun gyboüt diöh fir jür

The house is already built through four years

The house has been built for four years (i.e. someone has been building it)

Finally, the ej gymoht construction can be used in explicit past contexts indicating past passive situations, both simple (8.a), stative (8.b) and pluperfect (8.c) ones.

(8) a. Dos hoüz ej con jür y dom gyboüt

The house is ten years ago built

The house was constructed ten years ago (i.e. they built it)

b. Dy śtuw ej śun gymölt wi'h kom cyryk

The room is already painted when-I came back 
The room was already painted when I came back (i.e. it appeared as painted / it was ready)

c. Dy śtuw ej gymölt fynf śtunda ejer wał yh bej cyrykkuma The room is painted five hours earlier before I am come-back The room had been painted five hours before I came back (i.e. someone had painted it before I came)

\section{3. wiöe gymoht}

When the zajn passive employs the auxiliary in the simple past tense 'Preterite' - surfacing in the $3^{\text {rd }}$ person singular in the shape wiöe gymoht - it can express past resultative events triggering both dynamic (simple 9.a or pluperfect 9.b) and stative (past stative) (9.c) readings.

(9) a. Dos hoüz wiöe con jür y dom gyboüt

The house was ten years ago built

The house was / had been constructed ten years ago (i.e. they built it)

b. Der kłop wiöe derślön, dy śondorn zajn kuma

The man was killed before the police have come

The man had been killed before the police came (i.e. they had killed him before the police came)

c. Wi'h kom cyryk fur at, wiöe dy śtuw śun ufgyroümt

When-I came back from work, was the room already cleaned

When I came back from work, the room was / had been already cleaned (i.e. someone had already cleaned it / it was clean)

The formation may also have a past progressive or durative sense clearly opposite to the resultative (anterior) value of the sentences given in (9.b) and (9.c) above. In those instances, it indicates that an activity was in process of being performed in a particular moment in the past (10):

(10) Gestyn wiöe dy wond gymölt a gonca tog

Yesterday was the wall painted a whole day

Yesterday, the wall was being painted the whole day (i.e. someone was painting it)

A similar durative value may be observed in examples where the construction approximates an inclusive past perfect passive. In this function, someone 
had been performing a given activity from a given moment in the past to another past point of time:

(11) Dy kjyh wiöe remontiyt ejwerfunfcik jür bocar cajt, wen der krig oüsbruh

The church was repaired 50 years to-the time when the war began The church had been repaired for 50 years until the war began (i.e. they had been repairing it until the war began)

Due to a partial functional overlap between the Preterite and the Perfect, and in particular to the fact that the Preterite may be used instead of the Perfect in two prototypical perfect functions - commonly with the meaning of an experiential present perfect and less frequently as a resultative perfect (Andrason 2010a: 276 and 282-284), the wiöe gymoht passive can also express present perfect events (12.a and 12.b):

(12) a. Dos wiöe kamöł gymoht

This was never done

This has been never done (i.e. they have never done it / it is still undone)

b. S'oüta wiöe ny śun gyryht

The-car was not already repaired

The car has not been repaired yet (i.e. they have not repaired it yet / it is still broken)

\section{4. ej gywost gymoht}

The zajn passive may additionally employ the auxiliary verb in the Perfect providing dynamic present perfect meaning (13.a), simple past meaning (13.b) or pluperfect meaning (13.c):

(13) a. Zejhźe! Dos hoüz ej gywost ufgyśtelt

Look! the house is been built

Look, the house has been constructed (i.e. someone has built it)

b. Dos hoüz ej con jür y dom gywost ufgyśtelt

The house is ten years ago been built

The house was constructed ten years ago (i.e. someone built it)

c. Dos hoüz ej gywost ufgyśtelt funf jür bocar cajt, wen der krig oüsbruh 
The house is been built five years before-the time when the war began

The house had been constructed five years before the war began (i.e. someone had built it before the war began)

\section{5. wiöe gywost gymoht}

Finally, the zajn passive periphrasis in case it uses the auxiliary in the pluperfect tense - giving thus the shape wiöe gywost gymoht - invariably indicates pluperfect (dynamic or static) activities (14):

(14) Dos hoüz wiöe gywost ufgyśtelt bocar cajt, wen der krig oüsbruh

The house was been built before-the time when the was began

The house had been constructed before the war began (i.e. someone had built it before the war began)

\section{Wada passive}

Another passive construction is structurally analogous to the zajn passive differing only in the fact that this time the periphrasis employs the verb wada 'become' as an auxiliary instead of the predicate zajn. Similarly to the previously described formation, the introductory verb may be inflected in the Future, Present, Preterite, Perfect and Pluperfect tenses, and the passive locution itself may provide a broad range of meanings whose detailed description is presented below.

\section{1. wyt wada gymoht}

When the passive construction employs the auxiliary wada in the Future tense - appearing thus in the $3^{\text {rd }}$ person singular as wyt wada gymoht $t^{10}-$ the periphrasis expresses simple future events (15):

10 As already explained, explicit future activities are most frequently conveyed by the wada future which consists of the auxiliary wada and the infinitive of the main verb wyt moha 'will do' (Andrason 2010b). Thus, the future passive wyt wada gymoht employs the verb wada twice, i.e. as a future tense auxiliary wyt wada gymoht and as a passive voice auxiliary wyt wada gymoht. Other possible future locutions may use introductory verbs such as zuła 'shall', müssa 'must' or mygja 'may' (Andrason 2010b). 
(15) a. Wymysiöejer śpröh wyt nymer ny wada fergasa Vilamovicean language will never not become forgotten

The Vilamovicean language will never be forgotten (i.e. people will not forget it)

b. Dy wymysiöejer kyndyn wan ind gyljyt wada cy kuza wymysiöeryś

The Vilamovicean children will always taught become to speak Vilamovicean

Vilamovicean children will always be taught to speak Vilamovicean (i.e. people will always teach them how to speak Vilamovicean)

However, the same formation can denote future progressive activities (16):

(16) a. Mün wyt dos hoüz wada gymölt a gonca tog

Tomorrow will the house become painted a whole day

Tomorrow the house will be being painted the whole day (i.e. someone will be painting it)

b. Mün wyt dy hoüz wada reperiyt

Tomorrow will the house become repaired

Tomorrow, the house will be being reconstructed (i.e. someone will be reconstructing it)

Furthermore, when the auxiliary stands in the Future tense, the wada passive may also express future perfect (anterior) events, i.e. actions which will occur in the future time frame before other prospective activities (17):

(17) a. Zy kuza do dy kjyh wyt wada gyryht, ejer wał der fiöer wyt cyrykkuma

They say that the church will become restored earlier before the priest will come back

They say that the church will be restored before the priest comes (they will have restored before he comes)

b. Wen yh kum cyryk, wyt dy wond śun wada gymölt

When I come back, will the wall already be painted

When I come back, the wall will already be painted (i.e. some will have painted it) 


\section{2. wjyd gymoht}

When the wada auxiliary is inflected in the Present tense, the meaning of the periphrasis is - contrary to the zajn passive - most commonly future. This stems from the fact that when wada stands in the Present tense and is not used as an auxiliary introducing another verb, it denotes future events. In that function, it is frequently followed by a passive participle (as in our case), a noun, an adjective, or a prepositional phrase, and it means 'will be, will become' (cf. Andrason 2010b). It should be observed that in those cases the $3^{\text {rd }}$ person forms of the verb wada are systematically wjyd (singular) and wada (plural) instead of the form wyt and wan respectively, encountered in the examples where wada functions as the future auxiliary (cf. wyt moha 'he will do' or wyt gymoht zajn/wada 'will be(come) done'). It is interesting to note that in this usage, wada behaves like the Icelandic verb verða 'become, will be': hence, Vilamovicean haor wjyd ym hoüs is equivalent to Icelandic Hann verður heima 'He will be at home'.

The future value of the wjyd passive may be simple (with a bound unique reading close to the perfective future as in Polish) (18.a and 18.b), progressive (18.c) and perfect (anterior) (18.d):

(18) a. Fir draj jür wjyd dy śtrös gyboüt

For three year will/becomes the street built

The street will be built in three years (i.e. they will build it)

b. Wymysiöejer śpröh wjyd nymer ny fergasa

Vilamovicean language will never not become forgotten

The Vilamovicean language will never be forgotten (i.e. people will not forget it)

c. Mün wjyd dy hyt gymölt a gonca tog

Tomorrow will/becomes the wall painted a whole day

Tomorrow, the wall will be painted the whole day (i.e. someone will be painting it)

d. Zy kuza do fjyr fynf dy kjyh wjyd gyryht

11 This means that the present tense of Vilamovicean wada and Icelandic verða, in cases where the two predicates are used as lexical main verbs with the meaning 'become', has consistently a future reading, i.e. 'will become / will be'. Compare again the Vilamovicean sentence Haor wjyd mid 'He will be tired' with an analogous Icelandic expression Hann verður preyttur. 
They say that for 5 the church will become restored

They say that the church will be restored by five o'clock (i.e. they will have restored it by that time)

However, exactly the same formation can also be used to express dynamic present passive values, both progressive (19.a) and simple (19.b and 19.c):

(19) a. Wu ej s'oüta? S'wjyd eta grod gyryht

When is the-car? It becomes already right-now repaired

Where is the car? It is being repaired (i.e. someone is repairing it)

b. Dy oüta wada gyrjyt diöh dy benzyn

The cars become driven by the gas

Cars are propelled by gas (i.e. gas serves to propel cars)

c. Dy kyndyn wada azu ufgycün, do zy zuła śunn zajna ełdyn

The children become so educated that they should respect their parents

Children are educated so that they would respect their parents (i.e. parents habitually educate their children in that manner)

It should be noted that the wjyd gymoht periphrasis, when describing present activities, invariably pictures them as dynamic, contrary to a possible static lecture of the is gymoht expression (cf. 8.b).

\section{3. wiöd gymoht}

The auxiliary wada may also appear in the Preterite giving a dynamic past passive, in the $3^{\text {rd }}$ person singular wiöd gymoht. It seems that the meaning is invariably dynamic - simple (20.a), progressive (20.b) or pluperfect (anterior, 20.c) -, and thus never stative contrary to the examples with the auxiliary zajn in the same tense (cf. wiöe + passive participle in examples (9.c) above).

(20) a. Dos hoüz wiöd con jür y dom gyboüt The house became ten years ago built The house was built ten years ago (i.e. someone built it)

b. Gestyn wiöd dy wond gymölt a gonca tog

Yesterday became the wall painted a whole day

Yesterday, the wall was being painted the whole day (i.e. someone was painting it)

c. Der kłop wiöd derśłön, wał dy śondorn zajn kuma

The man became killed before the police have come 
The man had been killed before the police came (i.e. someone had killed him before the police came)

Furthermore, due to the already explained property of the Preterite being able to express some prototypical perfect meanings (e.g. resultative and experiential, cf. examples 12.a and 12.b above), the wiöd gymoht passive may be employed with the force of a present perfect. In that case, it describes anterior currently relevant events, either resultative or experiential.

(21) a. S'oüta wiöd ny śun gyryht

The-car became not already repaired yet

The car has not been repaired yet (i.e. they have not repaired it yet)

\section{4. ej gywoda gymoht}

When the wada passive employs the auxiliary in the Perfect, it normally provides the meaning of a prototypical dynamic present perfect (22.a). Nevertheless, due to the functional proximity between the Perfect and the Preterite (cf. Andrason 2010a), it can also indicate simple past (22.b) and pluperfect (22.c) events.

(22) a. Zejhźe! Dos hoüz ej śun gywoda reperiyt Look! the house is already become repaired Look, the house has already been reconstructed (i.e. someone has reconstructed it)

b. Dy kjyh ej con jür y dom gywoda ufgyśtelt

The church is ten years ago become built

The church was constructed ten years ago (i.e. someone built it)

c. Gestyn wi ej kuma dy nökweryn, dy kyh ej gywost śün ufgyroümt

Yesterday when is come the neighbor the kitchen is become already cleaned

Yesterday, when the neighbor came, the kitchen had already been cleaned (i.e. someone had cleaned it before the neighbor came)

\section{5. wiöe gywoda gymoht}

Finally, the wada passive can also use the auxiliary in the Pluperfect tense. In that case, the value of the periphrasis seems to be invariably pluperfect; it describes past anterior events, i.e. events which precede other past actions. It 
should be noted that, in contrast with the pluperfect zajn passive (wiöe gywost gymoht), the meaning is always dynamic and never stative.

(23) Dos hoüz wiöe gywoda ufgyśtelt bocar cajt, wen der krig oüsbruh

The house was become built before-the time when the was began The house had been constructed before the war began (i.e. someone had built it before the war began)

\section{Btajn passive}

The last passive construction encountered in the Vilamovicean language is a participial periphrasis - analogous to the two previously analyzed locutions, i.e. the zajn and wada passives - built on the verb blajn 'remain'. The expression seems to be significantly less common than the zajn and wada locutions, failing to be accepted by all the informants, in particular younger ones. On the other hand, the formation is more commonly employed by older speakers who were not forced to go to the German school during the Second World War. Vilamoviceans also relate that this passive construction was extensively used by people who had been born in the $19^{\text {th }}$ century. ${ }^{12}$ Finally, it should be noted that various informants, who accepted the błajn formation as correct, also suggested that other passive expressions, namely the zajn or the wada periphrases, "would sound better".13

\section{1. wyt błajn gymoht}

When the auxiliary verb stands in the Future tense receiving the form wyt błajn, the periphrasis may express all kinds of prospective activities, simple (24.a) durative-progressive (24.a) or resultative (future perfect) (24.b).

(24) a. Dy śtrös wyt błajn gyryht

12 According to our interviewees, some persons born in the $19^{\text {th }}$ century only used the błajn passive.

${ }^{13}$ In the case of Vilamovicean, it is hardly appropriate to speak about the correctness. It shall be observed that there is no such thing as a standard Vilamovicean. The language, even though limited to a small area and a scarce population, surprisingly includes some dialectal variations - this is especially evident in the lexicon. In consequence, people do not classify a given form as incorrect but rather propose an alternative solution, i.e. what they would say. 
The street will remain repaired

The street will be repaired (i.e. they will repair it)

b. Mün wyt dos hoüz błajn gymölt a gonca tog

Tomorrow will the house remain painted a whole day

Tomorrow, the house will be being painted the whole day (i.e. they will be painting it)

c. Wen yh kum cyryk, wyt dy wond śun błajn gymölt

When I come back will the wall already remain painted

When I came back, the wall will already be painted (i.e. someone will have painted it)

\subsection{Błajt gymoht}

In cases where the verb błajn stands in the Present tense, it provides various present meanings, such as simple (habitual, 25.a), progressive (25.b and 25.c), and resultative stative (25.d).

(25) a. Dy kyndyn błajt azu ufgycün, do zy zuła śunn zajna ełdyn The children remain so educated that they would respect their parents

The children are educated so that they would respect their parents (i.e. people educate the children)

b. Dos hoüz blajt eta grod gyboüt

The house remains already right-now built

The house is just right now being built (i.e. they are building it)

c. Wu ej s'oüta? S' błajt eta grod gyryht

Where is the-car? It-remains already right-now repaired

Where it the car? It is just being repaired

d. Dos hoüz błajt śun gyboüt

The house remains already built

The house is already built (i.e. it stands ready)

It should be noted that the btajn passive with the auxiliary in the Present tense - contrary to the zajn passive - does not denote perfect (anterior) or past activities so that the following sentences cannot be employed with the perfect, anterior or past force:

(26) a. Dos błajt śun gymoht

This remains already done 
*(intended meaning) This has already been done (i.e. someone has done it)

b. Dos hoüz błajt con jür y dom gyboüt

The house remains 10 years ago built

*(intended meaning) The house was built 10 years ago (i.e. someone built it 10 years ago)

\subsection{Bta gymoht}

When the auxiliary blajn appears in the Preterite, the construction may express a wide range of past values, indicating simple (27.a), progressive (27.b), stative and pluperfect activities (27.c). Additionally, the same expression can also correspond to a present perfect passive (27.d and 27.e).

(27) a. Gestyn, der kłop bła derślön

Yesterday the man remained killed

The man was killed yesterday (i.e. someone killed him)

b. Gestyn bła dy wond gymölt a gonca tog

Yesterday remained the wall painted a whole day

Yesterday, the wall was being painted the whole day (i.e. someone was painting it)

c. Der kłop bła śun derślön, dy śondorn zajn kuma

The man remained already killed when the police came

The man was already killed / had already been killed, when the police came (i.e. he was not alive / someone had killed him before)

d. Dos bła kamöł gymoht

This remained never done

This has never been done

e. S'oüta bla ny śun gyryht

The-car remained not already repaired

The car has not been repaired yet

\subsection{Ej gybłyjn gymoht and wiöe gybtyjn gymoht}

The introductory verb błajn may also be employed in the Perfect and Pluperfect. When it stands in the Perfect, the błajn passive construction does not 
only correspond to a present perfect (28.a) but also approximates prototypical simple past (28.b) and pluperfect categories (28.c):

(28) a. Zejhźe! Dos hoüz ej gybłyjn ufgyśtelt!

Look! The house is remained constructed

Look! The house has been built! (i.e. someone has built it)

b. Dos hoüz ej con jür y dom gybłyjn ufgyśtełt

The house is 10 years ago remained constructed

The house was built 10 years ago (i.e. someone built it 10 years ago)

c. Dos hoüz ej gybłyjn ufgyśtelt funf jür bocar cajt, wen der krig oüsbruh

The house is remained constructed 5 years before time when the war began

The house had been built 5 years before-the the war began (i.e. someone had built it before the war began)

Finally, using the auxiliary verb in the Preterite, the periphrasis expresses past stative and past perfect events (29):

(29) Dos hoüz wiöe gybłyjn ufgyśtelt bocar cajt, wen der krig oüsbruh The house was remained constructed before-the time the war began The house had been built before the war began (i.e. someone had built it before the war began)

\section{Conclusion}

In the previous sections of the article, we have demonstrated that one may distinguish three major ways of expressing passive meaning in the Vilamovicean language, namely the zajn, wada and blaj passive constructions - all of them consist of an auxiliary verb (zajn, wada or błaj respectively) and a passive participle. It has also been noted that the auxiliary included in each one of these formations may be inflected in the Future, Present, Preterite, Perfect and Pluperfect tenses giving rise to various specific uses and functions.

As for the zajn passive, the wyt zajn gymoht variant is used in all future functions (simple, progressive, perfect and stative). The ej gymoht expression is employed as a simple, progressive, perfect and stative present, and as a simple and perfect past. The wiöe gymoht construction approximates a simple, progressive, perfect and stative past as well as a present perfect. The ej 
gywost gymoht formation functions as a present perfect, simple past and past perfect; and the wiöe gywost gymoht sequence is employed as a pluperfect (past perfect).

In respect to the wada periphrasis, the wyt wada gymoht type denotes all future events (simple, progressive and perfect) except stative ones. The wjyd gymoht variant is employed as a simple, progressive and perfect future (equaling the wyt wada gymoht sequence) and as a simple and progressive present. The wiöd gymoht expression indicates present perfect situations as well as simple, progressive and perfect past (pluperfect) activities. The ej gywoda gymoht construction functions as a present perfect and as a simple and perfect past. Finally, the wiöe gywoda gymoht chain equals a past perfect.

The błajn passive is the least common passive periphrasis being accepted only by some - but on the other hand, the oldest, the most trustful and the least germanized - informants. In cases where it is viewed as admissible, the wyt błajn gymoht variant indicates all sorts of future events (simple, progressive, perfect and stative). The blajt gymoht locution expresses simple, progressive and resultative-stative present situations. The form bla gymoht usually denotes past (simple, progressive, perfective and stative) activities being also able to provide meanings which correspond to a present perfect. The $e j$ gybtyjn gymoht construction is employed as a present perfect and as a past (simple, progressive and perfect) while the wiöe gyblyjn gymoht conveys pluperfect passive values. All the evidence is summarized in the table below: 
Table: Passive constructions in the Vilamovicean language ${ }^{14}$

\begin{tabular}{|c|c|c|c|c|}
\hline \multicolumn{2}{|c|}{ Meaning } & Zajn passive & Wada passive & Btajn passive \\
\hline \multirow[t]{4}{*}{ Future } & simple & wyt zajn gymoht & $\begin{array}{l}\text { wyt wada gymoht } \\
\text { wjyd gymoht }\end{array}$ & wyt błajn gymoht \\
\hline & progressive & wyt zajn gymoht & $\begin{array}{l}\text { wyt wada gymoht } \\
\text { wjyd gymoht }\end{array}$ & wyt błajn gymoht \\
\hline & perfect & wyt zajn gymoht & $\begin{array}{l}\text { wyt wada gymoht } \\
\text { wjyd gymoht }\end{array}$ & wyt błajn gymoht \\
\hline & stative & wyt zajn gymoht & & wyt błajn gymoht \\
\hline \multirow{4}{*}{ Present } & simple & ej gymoht & wjyd gymoht & błajt gymoht \\
\hline & progressive & ej gymoht & wjyd gymoht & blajt gymoht \\
\hline & perfect & $\begin{array}{l}\text { ej gymoht } \\
\text { wiöe gymoht } \\
\text { ej gywost gymoht }\end{array}$ & $\begin{array}{l}\text { wiöd gymoht } \\
\text { ej gywoda gymoht }\end{array}$ & $\begin{array}{l}\text { bła gymoht } \\
\text { ej gybtyjn gymoht }\end{array}$ \\
\hline & stative & ej gymoht & & błajt gymoht \\
\hline \multirow{4}{*}{ Past } & simple & $\begin{array}{l}\text { ej gymoht } \\
\text { wiöe gymoht } \\
\text { ej gywost gymoht }\end{array}$ & $\begin{array}{l}\text { wiöd gymoht } \\
\text { ej gywoda gymoht }\end{array}$ & $\begin{array}{l}\text { bła gymoht } \\
\text { ej gyblyjn gymoht }\end{array}$ \\
\hline & progressive & wiöe gymoht & wiöd gymoht & bła gymoht \\
\hline & perfect & $\begin{array}{l}\text { ej gymoht } \\
\text { wiöe gymoht } \\
\text { ej gywost gymoht } \\
\text { wiöe gywost } \\
\text { gymoht }\end{array}$ & $\begin{array}{l}\text { wiöd gymoht } \\
\text { ej gywoda gymoht } \\
\text { wiöe gywoda } \\
\text { gymoht }\end{array}$ & $\begin{array}{l}\text { bła gymoht } \\
\text { ej gybtyjn gymoht } \\
\text { wiöe gybtyjn } \\
\text { gymoht }\end{array}$ \\
\hline & stative & $\begin{array}{l}\text { ej gymoht } \\
\text { was gymoht } \\
\text { ej gywost gymoht } \\
\text { wiöe gywost } \\
\text { gymoht }\end{array}$ & & $\begin{array}{l}\text { bła gymoht } \\
\text { ej gyblyjn gymoht } \\
\text { wiöe gybtyjn } \\
\text { gymoht }\end{array}$ \\
\hline
\end{tabular}

As a general conclusion extrapolated from the data presented in the present article, one may suggest the following.

14 The grey squares represent meanings which are incompatible with a given construction. In all the squares, the subtypes of the three passive periphrases have been arranged so that the auxiliary verbs appearing in the same horizontal line would correspond to the same tense (Future, Present, Preterite, Perfect or Pluperfect). 
First, the Vilamovicean passive voice is not limited to the wada expression (itself restricted to three tenses, cf. Lasatowicz 1992: 74-75) but is conveyed by three periphrastic locutions built on auxiliary verbs zajn, wada and błajn, each one employed in five possible tenses (Future, Present, Preterite, Perfect and Pluperfect). In that manner, Vilamovicean employs the three main ways (built on auxiliary verbs ${ }^{15}$ ) of expressing the passive meaning, available in the Germanic family: the zajn formation (as in English is done as well as in other languages), the wada construction (as in German wird gemacht and in the case of the wada in the Present tense as in Icelandic verður gerður 'will be done') and the błajn periphrasis (as in Scandinavian languages such as Swedish blev gjort 'was done').

Second, the main difference between the zajn passive and the wada construction consists in the fact that the former (but not the latter) can provide stative values - thus, the meaning of the wada periphrases is invariably dynamic - and that the latter (but not the former) in the Present tense (i.e. wjyd gymhot) most commonly expresses future events.

Third, the blajn passive - nowadays, a less common manner of conveying the passive value - displays a similar behavior to that of the zajn formation: namely, it is able to express stative meanings. The only difference is that the blajt gymoht expression (with the verb in the Present tense) cannot be used as a past stative contrary to the ej gymoht. On the other hand in all the remaining uses, the locution approximates the wada periphrasis.

The dissimilarities in the meaning of the three passive constructions certainly stem from the different semantic load of the employed auxiliary. In particular, the verb wada has a more evident dynamic character than the predicates zajn and błajn. When used as a concrete non-auxiliary verb, it signifies 'become, turn into' while the latter verbs can offer more static readings: 'be' and 'remain' respectively. This explains the incompatibility of the wada passive with the stative meaning. However, it should be observed that in various passive functions the value of the three periphrases is highly similar, if not identical. For instance, passive simple past events - analogous to that conveyed by the English sentence It was done 10 years ago - can be expressed by the following, fully synonymous (in this precise function), constructions: wiöe gymoht, wiöd gymoht and bła gymoht.

15 The other common way of conveying the passive meaning is the use of reflexive forms such as the Swedish form boken skrevs 'the book was written'. 


\section{Bibliography}

ANDRASON A., 2008a, Vilamovicean and the language contact phenomenon - the influence of Polish on the smallest Germanic language, Talk presented at the Institute of Linguistics, University of Manchester. May 6, 2008.

Andrason A., 2008b, Do the Preterit and the Perfect mean the same? Some remarks on the Vilamovicean verbal system from the grammaticalization perspective, Talk presented at the Indo-European Seminar Series at the Department of Classics, University of Cambridge. December 3, 2008

Andrason A., 2009, Expressions of futurity in the Vilamovicean language, Talk presented at the School of Oriental and African Studies SOAS, University of London. October 21, 2009.

Andrason A., 2010a, Vilamovicean verbal system - Do the Preterite and the Perfect mean the same?, Linguistica Copernicana 3, p. 371-285.

Andrason A., 2010b, Expressions of futurity in the Vilamovicean language, SPIL PLUS 40, p. 1-11.

Bybee J., Perkins R., Pagliuca W., 1994, The Evolution of Grammar, Chicago-London: The University of Chicago Press.

DAHL Ö., 2000, The Tense and Aspect Systems of European Languages in a Typological Perspective, in: Östen Dahl (ed.), Tense and Aspect in the Languages of Europe, Berlin-New York: Mouton de Gruyter, p. 3-25.

DANEK J., 2007, Wymysöjer śtytta, Wilamowice: Miejsko-Gminny Ośrodek Kultury.

DobczyŃski W., 2002, Śpiewnik Gminy Wilamowice, Wilamowice: Gmina Wilamowice.

GARA J., 2006, Zbiór piosenek wilamowskich, Wilamowice.

Kleczkowski A., 1920, Dialekt Wilamowic w zachodniej Galicji. Fonetyka i fleksja, Kraków: PAN.

Lasatowicz M., 1992, Die deutsche Mundart von Wilamowice zwischen 1920 und 1987, Opole: Wyższa Szkoła Pedagogiczna.

MŁynek L., 1907, Narzecze wilamowickie, Tarnów: J. Pisz.

Wicherkiewicz T., 2004, The Making of a Language, Trends in Linguistics. Documentation 19, Berlin-New York: Mouton de Gruyter. 


\section{Strona bierna w języku wilamowskim}

\section{(streszczenie)}

Celem niniejszego artykułu jest szczegółowy opis konstrukcji składniowych wprowadzających stronę bierną w języku wilamowskim. Analiza materiału zgromadzonego podczas badań terenowych w Wilamowicach w roku 2009 i 2010 dowodzi, iż wilamowski ma nie jedną, jak dotychczas twierdzono, lecz trzy peryfrastyczne formacje pasywne. Konstrukcje te składają się z czasowników posiłkowych zajn, wada lub błajn - mogących pojawić się w czasie teraźniejszym, przyszłym, przeszłym złożonym (perfekcie), przeszłym prostym (preteritum) i zaprzeszłym - oraz $\mathrm{z}$ nieodmiennego imiesłowu biernego. Użycie tych formacji, choć w wielu wypadkach zbliżone, nie jest identyczne. Na przykład, strona bierna z zajn oraz błajn wyróżnia się tym, iż ma znaczenie statyczne, podczas gdy konstrukcja z czasownikiem wada niezmiennie wyraża znaczenie dynamiczne. Inna różnica dotyczy częstości użycia. Formacje z zajn i wada są uznawane za poprawne przez wszystkich informatorów, strona bierna z błajn jest konstrukcją używaną jedynie przez najstarszych Wilamowian, w szczególności przez tych, którzy nie zostali poddani germanizacji w czasie drugiej wojny światowej. 
